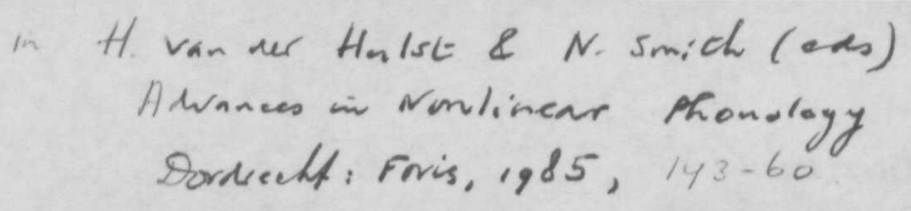

\title{
Coordination Reduction in Complex words: a Case for Prosodic Phonology
}

\author{
Geert E. Booij
}

Free University Amsterdam

\section{INTRODUCTION ${ }^{1}$}

Both Dutch and German exhibit a rather peculiar type of coordination reduction whereby parts of complex words are deleted under identity with parts of complex words in the same phrase. The following examples, cases of coordinated compounds, illustrate this:

(1) Dutch:

$\left[[\text { minimum }]_{N}[b \notin ₫ t d q \notin \emptyset]_{N}\right]_{N}[e n]_{C}\left[[\text { maximum }]_{N}[\right.$ bedra-

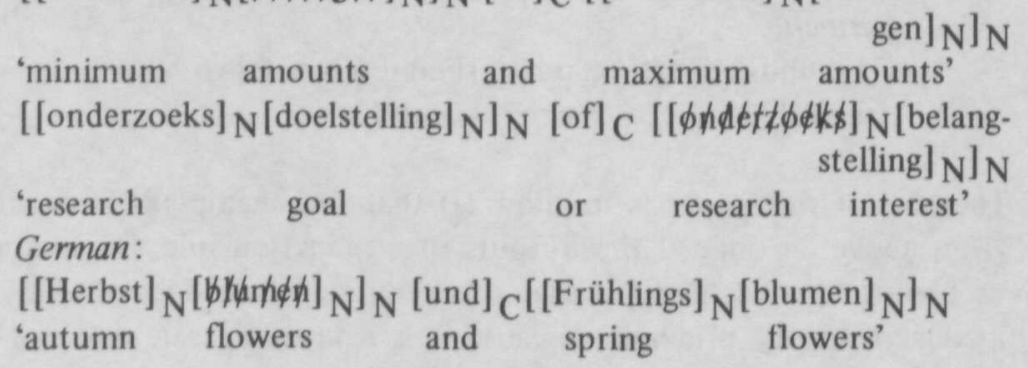

This type of coordination reduction is peculiar in that internal parts of words are affected by a deletion rule that looks like a syntactic rule, since it is conditioned by the presence of coordination. Thus, this phenomenon seems to violate the principle of Lexical Integrity, which states that the internal structure of words is opaque to syntax, a principle that is also known as the Generalized Lexical Hypothesis (Lapointe 1979: 22) or the Word Structure Autonomy Condition (Selkirk 1982: 70). ${ }^{2}$

A second peculiarity involved here is that deletion can take place even when the identical parts have a different morphological/syntactic status. In the following examples the deleted constituent is part of a compound, whereas the identical counterpart is an independent word, or vice versa:

$$
\begin{aligned}
& \text { Dutch: } \\
& {\left[\left[[i j s]_{N}[b \notin t \phi \hbar]_{N}\right]_{N}\right]_{N P} \text { en }\left[[\text { bruine }]_{A}\right.} \\
& \text { "polar bears beren } \left.]_{N}\right]_{N P}
\end{aligned}
$$




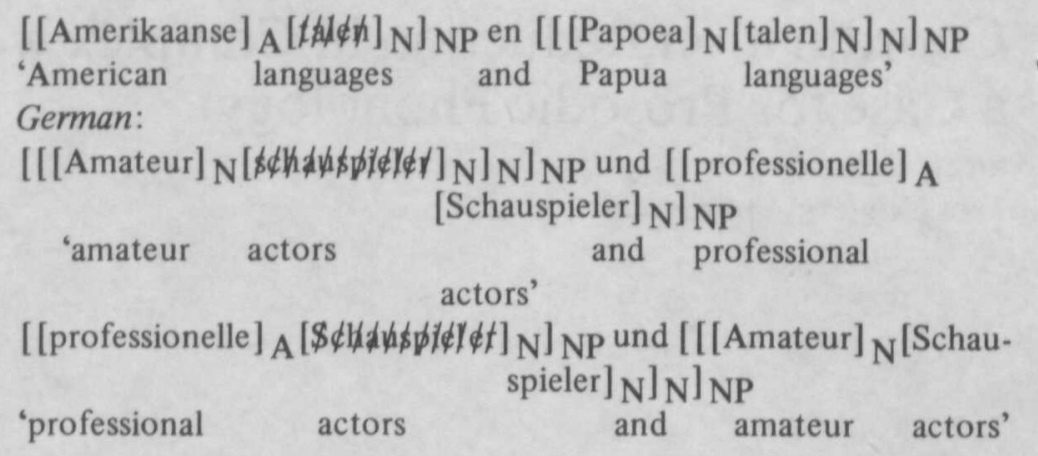

Thirdly, we also find cases of reduction in which a suffix has been deleted. The examples in (3) illustrate the possible deletion of the Dutch suffix -schap and its German counterpart -schaft:

(3) Dutch:

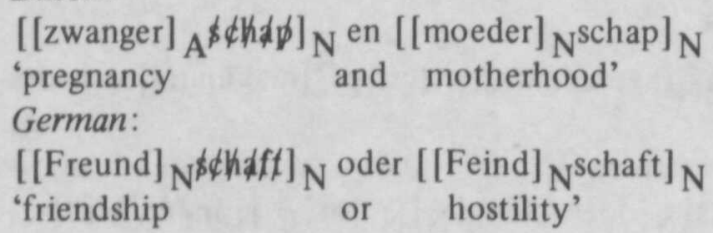

The aim of this paper is to show (i) that the examples of coordination given above are indeed the outputs of a reduction rule, i.e. they cannot be base-generated, and (ii) that this reduction rule does not violate the Lexical Integrity principle, because it is a prosodic rule and not a syntactic one. Consequently, proof is offered for the relevance of an independent prosodic structure - which is related to, but not necessarily isomorphic to, syntactic/morphological structure. Finally, some conclusions will be drawn with respect to the model of rule ordering proposed in Selkirk (1980a).

\section{EVIDENCE FOR THE DELETION HYPOTHESIS}

The preliminary question that I want to go into is whether it is justified to assume that the constructions (1)-(3) are the products of deletion. Why don't we interpret a phrase such as minimum- en maximumbedragen as a compound, the first part of which is a coordination of two words? This type of compound must be admitted anyway for Dutch, since we find words like the following: 


$$
\begin{aligned}
& \text { kat-en-muis-spelletje } \\
& \text { gooi-en-smijt-films }
\end{aligned}
$$

'cat-and-mouse-game'

'throw-and-fling-films'

We cannot interpret these words as cases of reduction. For instance, kat-en-muis-spelletje is not to be interpreted as katspelletje en muisspelletje 'cat's game and mouse's game', but as 'game between cat and mouse'.

On the other hand, there are arguments for the correctness of the deletion hypothesis for cases such as (1)-(3). A first argument can be derived from constructions like (5):

het verschil tussen een derdek $\mid \$ \$ \$ \$ \downarrow l$ en een zesdeklasser 'the difference between a third-former and a sixth-former'

This phrase cannot be base-generated, because that would imply that derde and een zesde are coordinated. This is impossible, because een zesde is not a constituent. Moreover, the preposition tussen 'between' requires a complement with plural meaning, whereas a base-generated compound derde-en-een-zesde-klasser would have a singular interpretation, since the head klasser is singular.

A second source of evidence is provided by the following examples from Dutch:

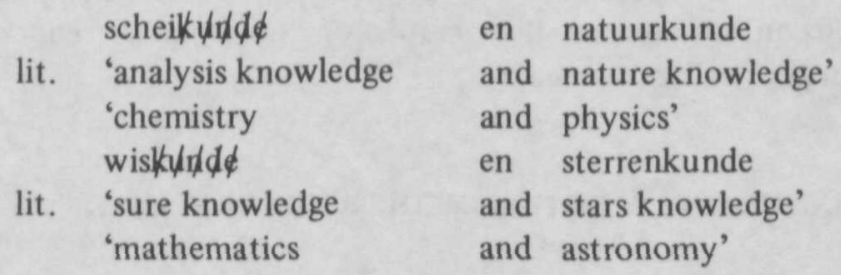

The morphemes schei and wis in these examples are very idiosyncratic. Schei, with the meaning 'to analyze', does not occur as an independent word. ${ }^{3}$ The adjective wis 'sure, certain' only occurs in a few frozen expressions such as wis en waarachtig 'for sure'. Thus, the combinations of these morphemes with kunde 'knowledge' have very idiosyncratic meanings, to be listed in the lexicon. The deletion hypothesis predicts that these idiosyncratic meanings recur in the constructions (6), whereas the hypothesis of base generation does not. Moreover, the latter hypothesis would also imply that we have to admit the coordination of con-

- stituents of different syntactic categories, since, for example, wis is an adjective and sterren is a noun. This also applies to a construction like leer-en handboeken 'lit. learn- and hand books, text and hand books', - in which leer is a verb, but hand a noun. 
The last kind of evidence in favour of the deletion hypothesis that I want to present here concerns the occurrence of a link phoneme, [2] or [s] in Dutch compounds, e.g. in [[wesp]e[steek]] 'wasp sting' and [[zon]s[verduistering] 'sun eclipse'. These link phonemes also occur in constructions such as:

$$
\begin{aligned}
& \text { [wesp]e[ } \$\langle| \phi k \notin n] \text { en [bij] [steken] } \\
& \text { 'wasp stings and bee stings' }
\end{aligned}
$$

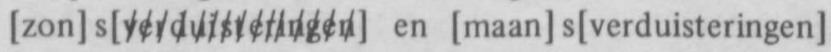

$$
\begin{aligned}
& \text { 'sun eclipses and moon eclipses' }
\end{aligned}
$$

Suppose now that we base-generate [[[wesp $]$ en [bij]][steken]]. This would imply that the link phoneme [ $[$ ] has to be inserted into this structure by some morphological rule. However, Toman (1981) has argued that coordinated minimal projections $\left(\mathrm{X}^{\mathrm{O}}\right.$-projections) are inaccessible for morphological rules. ${ }^{4}$ This explains, for example, why Dutch has the ordinal [[drie-en-zestig] ste] 'lit., three-and-sixtieth, sixty-third', since the morphological rule of ordinal formation has no access to the internal structure of drie-en-zestig. Otherwise, the incorrect form *derde-enzestigste 'lit. third-and-sixtieth' would have been derived. Thus, the introduction of link phonemes would violate Toman's restriction. On the other hand, the deletion hypothesis does not violate this restriction, because wespe-en bijesteken is derived from wespesteken en bijesteken.

In conclusion, it appears that a rule of coordination reduction in complex words is well motivated.

\section{THE STRUCTURAL DESCRIPTION OF THE REDUCTION RULE}

Let us now take a closer look at the syntactic configurations in which we find the aforementioned reduction. The presence of some form of coordination is essential. I assume the following rule schema for non-initial coordination (cf. Jackendoff (1977: 50) and Neijt $(1979: 5,66))$ :

$$
\begin{array}{ll}
X^{i} \rightarrow X^{i}\left(\operatorname{conj} X^{i}\right)^{n} & n \geqslant 1 \quad i \geqslant 0 \\
& X=N, A, V, P, Q
\end{array}
$$

In principle, we find reduction in all structures generated by (8). The following examples serve to illustrate this: 
(9) $\mathrm{X}=\mathrm{N}$, coordination of N's

$[\operatorname{land} \phi \phi \psi w]_{\mathrm{N}}$ en [tuinbouw] $\mathrm{N}$

'agriculture and horticulture'

coordination of NP's:

[de land $\left.\phi \phi \psi w w_{N}\right]_{N P}$ en [de tuinbouw] ${ }_{N P}$

'the agriculture and the horticulture'

$\mathrm{X}=\mathrm{A}$, coordination of $\mathrm{A}$ 's

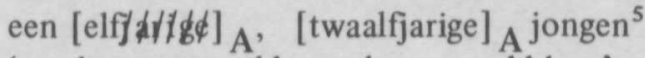

'an eleven year old, twelve year old boy'

$\mathrm{X}=\mathrm{P}$, coordination of $\mathrm{P}$ 's

[voorit $]_{P}$ of [achterin] $P$ de boot

'in the front or at the back of the boat'

$\mathrm{X}=\mathrm{V}$, coordination of $\mathrm{V}$ 's:

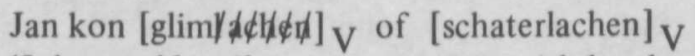

'John could smile or roar with laughter'

coordination of VP's (V')

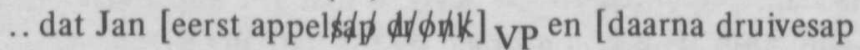

'that John first apple juice drank and then grape juice dronk] VP

drank'

coordination of S's $\left(\mathrm{V}^{\prime \prime}\right)$ :

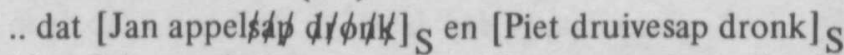

'that John apple juice drank and Peter grape juice drank'

coordination of $\overline{\mathrm{S}}$ 's $\left(\mathrm{V}^{\prime \prime \prime}\right)$ :

Jan vroeg [wie er appel\$d $\phi \quad d / \phi d k]_{\bar{S}}$ en

'John asked who there apple juice drank and

[wie er druivesap dronk] $\bar{S}$

who there grape juice drank'

$\mathrm{X}=\mathrm{Q}$, coordination of $\mathrm{Q}$ 's

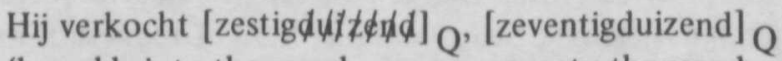

"he sold sixty thousand , seventy thousand

exemplaren

copies'.

Following Neijt (1979: 5) I assume that initial coordination is only possible for maximal projections of lexical categories. The relevant rule schema is (10):

(10) $X^{i} \rightarrow\left(\operatorname{conj} X^{i}\right)^{n}$, i maximal, $n \geqslant 2$.

An example of reduction in a structure with initial coordination is: 
(11) hetzij hoofd $\phi \notin \notin$ dy, hetzij nevenaccent

'either main stress or secondary stress'

In the examples (9) and (11) deletion has taken place on the left side of the conjunction. However, as we already saw in (1), it is also possible to delete on the right side, as shown in (12):

$$
\begin{aligned}
& \text { Dutch: }
\end{aligned}
$$

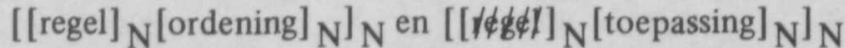

$$
\begin{aligned}
& \text { 'rule ordering and rule application' } \\
& \text { German: }
\end{aligned}
$$

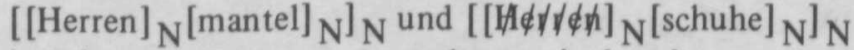

$$
\begin{aligned}
& \text { 'men's coats and men's shoes' }
\end{aligned}
$$

The data presented so far suggest that the gap must be adjacent to the conjunction. This is confirmed by the data in (13):

i. *in the land $\phi \phi \dot{\psi} w$ van Nederland en de tuinbouw van Belgie 'in the agriculture of Holland and the horticulture of Belgium'

ii. *.. dat Jan appel\$\$p dronk en Piet druivesap dronk 'that John apple juice drank and Peter grape juice drank'

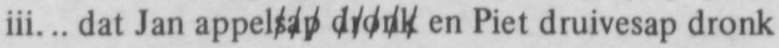
'that John apple juice drank and Peter grape juice drank'

In (13i) and (13ii) the gap is separated from the conjunction, and hence they are ungrammatical. In (13iii) the verb dronk has also been deleted (by V-deletion) and thus the gap of sap is adjacent to the conjunction. The ungrammaticality of the example of right reduction in (14) also confirms this condition:

*de regelordening en de $t \notin g \notin$ toepassing 'the rule ordering and the rule application'

The next question to be asked is: what is the nature of the deleted constituent? Should it be defined phonologically, morphologically or syntactically? Phonological identity is not sufficient: witness, for example, the ungrammatical phrase *vo\$фl\$ en vlegels "birds and impertinent persons'. The same holds for morphological identity, as shown by the ungrammaticality of the reductions in (15): 
(15) Dutch:

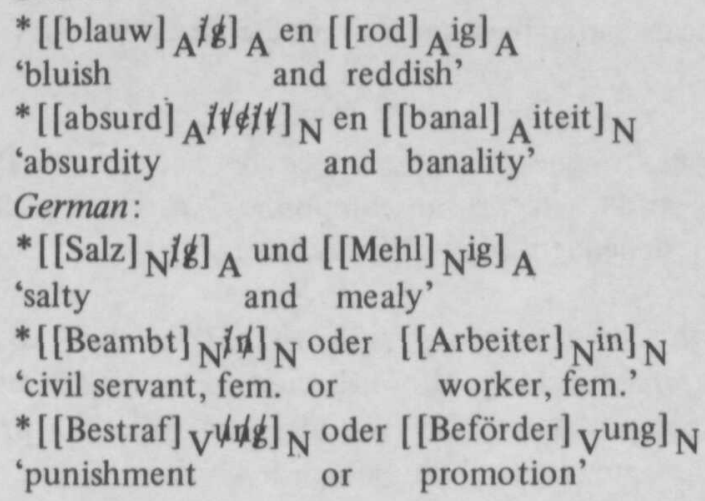

It should also be remembered that deletion can take place although the identical consitituents do not share the same syntactic status (cf. (2)).

My answer to the problem of the nature of the deletable constituents is that they are phonological words (or projections thereof). By means of the notion 'phonological word' we can express the fact that there is not always a one-to-one-correspondence between syntactic words and their phonological correlates. In some languages, articles, clitics and the like are not independent phonological words, but fuse phonologically with a preceding or following word. Classic examples are the Latin conjunctions -que 'and' and -ve 'or', which fuse with the preceding word. On the other hand, a phonological word may also be smaller than a syntactic word. For instance, the constituents of Dutch compounds (and also certain affixes cf. section 4) have to be considered independent phonological words. This is clear from their syllabification patterns: the internal morphological boundaries of compounds always coincide with a syllable boundary, even when this would violate the Maximal Onset Principle. The following minimal pairs illustrate this:

(16)

$\begin{array}{cl}\text { i } & \text { [balk] [anker] } \\ & {[\text { bal] [kanker] }} \\ \text { ii } & {[\text { wet]s[taal] }} \\ & {[\text { wet] [staal] }}\end{array}$

'beam brace'
'testicle cancer'
'legal language'
'knife sharpener'

syllabification: (balk) ${ }_{\sigma}$ (an) ${ }_{\sigma}(\text { ker })_{\sigma}$ (bal) ${ }_{\sigma}(\mathrm{kan})_{\sigma}(\mathrm{ker})_{\sigma}$ (wets) $_{\sigma}$ (taal) $\sigma$ (wet) ${ }_{\sigma}$ (staal) $\sigma$

The fact that the phonological word is the domain of syllabification follows from Selkirk's prosodic theory (Selkirk 1978, 1980a, b) which as- sumes the prosodic hierarchy of syllable $(\sigma)$, foot $(\mathrm{F})$, phonological word $(\omega)$, phonological phrase $(\varphi)$, intonational unit (I) and utterance (U). Since $\sigma$ is a subdomain of $\omega$, two segments of the same $\sigma$ cannot belong - to different $\omega$ 's. 
Let us assume now the following provisional rule for the mapping of syntactic/morphological hierarchies onto prosodic ones for Dutch and German:

(17) There is a one-to-one-correspondence between syntactic and phonological words, except for compounds, in which each constituent is an independent phonological word.

This rule explains why reduction is possible in phrases such as Amerikaanse $t d l \phi \eta$ en Papoeatalen (cf. 2): although the two talen's are different from the syntactic point of view, they are identical from the prosodic point of view, since they are identical phonological words.

As van der Zee (1982: 85) points out in relation to the syntactic rule of Gapping, the acceptability of the outputs of rules of coordination reduction is also dependent on intonation: remnants and their counterparts have to be stressed, must function as focus constituents. For example, in Amerikaanse - en Papoeatalen the remnant Amerikaanse and its counterpart Papoea-must receive stress.

The requirement that there is some remnant that functions as a focus constituent also explains the ungrammaticality of the reductions in (18) and (19i):

* $\ \phi \phi \gamma \phi \phi \notin d \phi \phi$ en tegenvoorbeelden
'examples and counterexamples'
i *Blenheimbommenw $\phi \downarrow \phi \notin\rangle$ \& en Beaufortbommenwerpers
'Blenheim bombers and Beaufort bombers
ii landbouwnd $\phi$ hitip $\phi$
en tuinbouwmachines
'agricultural machinery
and horticultural machinery'

In (18) there is no remnant; in (19i) the remnant Blenheimbommen is not a constituent: the morphological and corresponding prosodic structure of Blenheimbommenwerper are as follows:

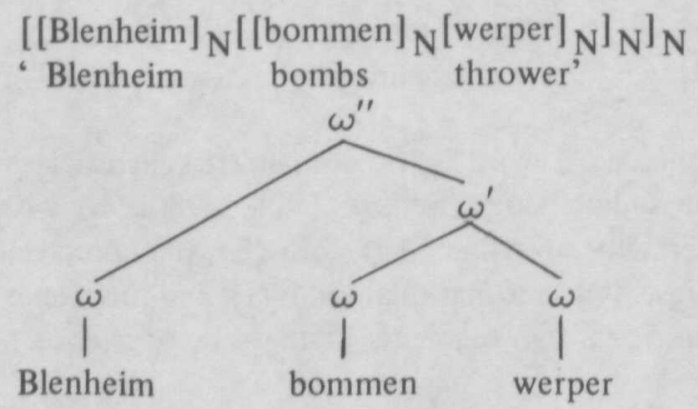


But the morphological and prosodic structure of landbouwmachines is - different: [[land] [bouw]] [machines]] and $\left((\right.$ land $\left.) \omega^{(\text {bouw })} \omega\right) \omega^{\prime}($ machines) $\omega^{\prime} \omega^{\prime \prime}$ respectively, Thus, the remnant Blenheimbommen cannot function as a focus-constituent, because it is not one, whereas the remnant landbouw can. Note, moreover, that not only phonological words, but also projections thereof can be deleted, since bommenwerper is a $\omega^{\prime}$.

In conclusion, the rule of coordination reduction in complex words can be formulated as follows:

Coordination reduction (optional)

Delete Y. Conditions: (i) $\mathrm{Y}=\omega^{\mathrm{m}} \quad \mathrm{m} \geqslant 0$

(ii) $\mathrm{Y}$ is adjacent to a conjunction

(iii) There is a remnant that, like its counterpart, can function as focus constituent.

$\mathrm{I}$ assume that the requirement that $\mathrm{Y}$ must have an identical counterpart follows from the principle of recoverability of deletions. ${ }^{6}$

\section{REDUCTION IN COMPLEX WORDS WITH AFFIXES}

Rule (21) predicts that those affixes which form independent phonological words can in principle be deleted. This prediction is correct, both for Dutch and German, as the examples in (22) illustrate:

(22) Dutch:

$$
\begin{aligned}
& \left.\left[[\text { zwanger }] A^{\$ \notin h d \not p]}\right]_{N} \text { en [[moeder }\right]_{N}^{\text {schap }]_{N}} \\
& \text { 'pregnancy and motherhood' }
\end{aligned}
$$

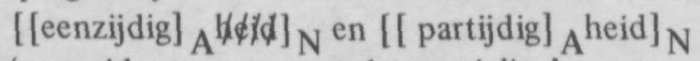

$$
\begin{aligned}
& \text { 'one-sideness and partiality' }
\end{aligned}
$$

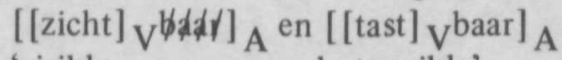

$$
\begin{aligned}
& \text { 'visible and tangible' }
\end{aligned}
$$

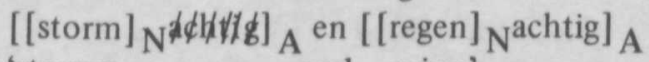

$$
\begin{aligned}
& \text { 'stormy and rainy' } \\
& {\left[\text { [eer] } \mathrm{N}^{\not \alpha d \boldsymbol{q} \not h]} \mathrm{A} \text { en [[deugd] } \mathrm{N}^{\text {zaam }]} \mathrm{A}\right.} \\
& \text { 'respectable and virtuous' } \\
& \left.\left[\text { [oever] }{ }_{N} \backslash \phi \phi \delta\right]_{A} \text { en [ [zoute }\right]_{N}{ }^{\text {loos] }} \mathrm{A} \\
& \text { 'lit. bankless and saltless, endless and insipid' }
\end{aligned}
$$

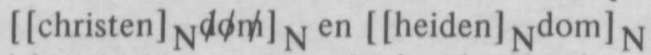

$$
\begin{aligned}
& \text { 'christianity and heathendom' }
\end{aligned}
$$




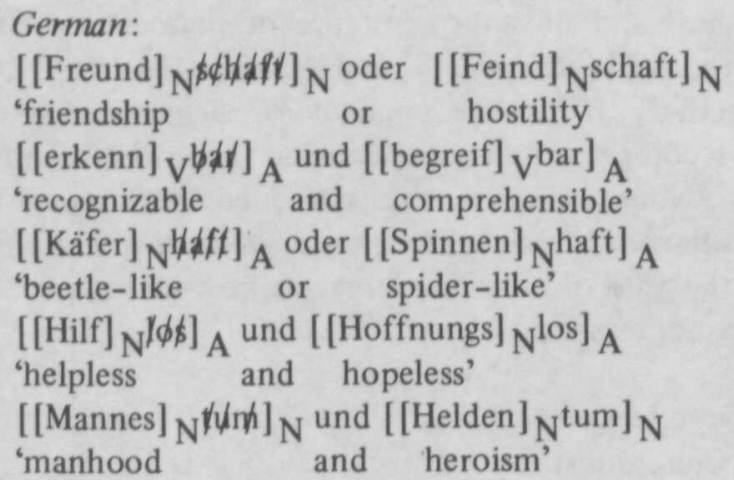

There is independent evidence for the phonological word status of the Dutch and German suffixes discussed here. First, they have the same stress patterns as compounds, which follows in this theory from the fact that both compounds and complex words with these suffixes consist of (at least) two phonological words, the first of which is the strong one. Second, these suffixes function as independent domains of syllabification, that is, the morphological boundary before these suffixes always coincides with a syllable boundary. The interesting cases are those complex words for which the normal principles of syllabification such as the Maximal Onset Principle would predict different syllabification patterns if the suffixes did not form phonological words on their own. Compare:?

(23) Dutch:

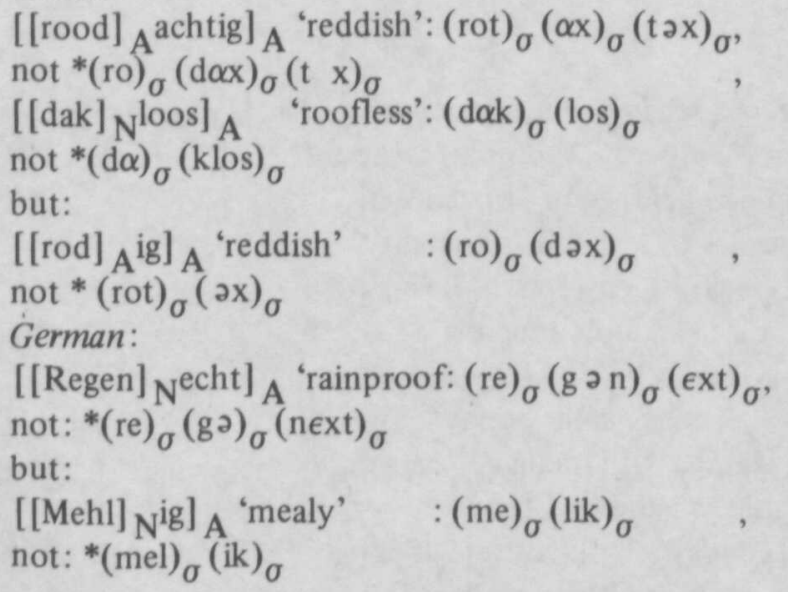

Third, in Dutch the rule of prevocalic schwa-deletion applies before all vowel-initial suffixes except -achtig, the only vowel-initial suffix that admits coordination reduction. Compare e.g. $\left[\left[_{\text {zijde }}{ }_{\left.N^{a c h t i g}\right]_{A}}\right.\right.$ 'silklike' with $\left[[z i j d \phi]_{\mathrm{N}} i g\right]_{\mathrm{A}}$ 'silky'. This follows from the assumptions that 
the domain of the rule of prevocalic schwa-deletion is the phonological - word:

$$
\left.{ } \rightarrow \varphi /-V_{\ldots . .}\right)_{\omega}
$$

and that -achtig is a phonological word.

The last kind of evidence concerns German. In German, a glottal stop can be inserted before a vowel-initial word. This glottal stop also occurs within compounds if the second part is vowel-initial, and before the suffix -echt, but never before the other vowel-initial suffixes of German like -ig, $-i s c h,-i n$ etc., which do not form independent phonological words.

Note, moreover, that from the diachronic point of view the phonological word-status of these Dutch and German suffixes is understandable, since they have all developed from early Germanic syntactic words.

From now on, I will refer to affixes which fuse with an adjacent phonological word as 'cohering affixes' and to the other ones as 'non-cohering affixes'. $^{8}$

When a cohering suffix is attached to a base word that consists of more than one phonological word, this suffix fuses with the preceding phonological word. Thus we get prosodic structures like the following:

$$
\begin{aligned}
& \text { morphological structure: } \\
& \text { [[ [gemak] [zucht]] ig] 'easy-going' (gemak) } \omega^{\text {(zuchtig) } \omega} \\
& \text { [[ [binnen] [land] ] s] 'interior, inland-' (binnen) } \omega^{(\text {lands) }} \omega
\end{aligned}
$$

In (25) the strings zuchtig and lands are not constituents from the morphological point of view. Yet they are prosodic constituents. Therefore, deletions like the following are possible:

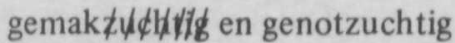

$$
\begin{aligned}
& \text { 'easy-going and pleasure-loving' } \\
& \text { binnen/dnd } \phi \bar{\phi} \text { en buitenlands beleid } \\
& \text { 'home and foreign policy' }
\end{aligned}
$$

This asymmetry between morphological and prosodic structure also manifests itself in the behaviour of link phonemes with respect to coordination reduction. From the morphological point of view the link phoneme does not belong to one of the constituents of the compound: it links them.

- However, from the prosodic point of view they belong to the first phonological word, as illustrated in (27): 


$$
\begin{aligned}
& \text { [pruim] e [boom] 'plum tree': }\left((\text { prui) })_{\sigma}\left(\mathrm{me}_{\sigma}\right)_{\sigma}{ }_{\omega}(\text { boom })_{\omega}\right. \\
& \text { [onderzoek] s[belangstelling] 'research interest': } \\
& \text { (onderzoeks) }{ }_{\omega} \text { (belangstelling) } \omega
\end{aligned}
$$

Consequently, when reduction applies on the left side of the conjunction, the link phoneme does not disappear, whereas it does disappear under reduction on the right side:

$$
\begin{aligned}
& \text { pruime } \phi \phi \phi h \text { of appelboom 'plum tree or apple tree' } \\
& \text { onderzoeksdoelstelling of } \phi \phi d \phi\rangle \phi \phi \mid \psi \$ \text { belangstelling } \\
& \text { 'research goal or research interest' }
\end{aligned}
$$

So far, we have only discussed complex words with suffixes, but reduction is also possible in complex words with prefixes:

\section{(29) Dutch:}

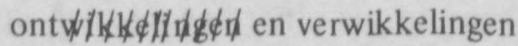

'developments and complications'

ont\$1dàn en bestaan

'origin and existence'

ondidy i $\phi$ ndaly of zelfs antinationaal

'unnational or even antinational'

minder y

"less fertile

or even infertile'

German:

Er möchte ihn zerhiduфu oder verhauen

'He wants to cut him up or to beat him up'

Sie möchte ein/\$dфứ, er möchte entladen

'she wants to load, he wants to unload'

Again, there is independent evidence that Dutch and German prefixes are non-cohering. ${ }^{9}$ First, the final schwa of the Dutch prefixes be- and ge-does not disappear before a vowel-initial stem:

$$
\begin{array}{lll}
\text { bə-aamd } & \text { *baamd } & \text { 'assented' } \\
\text { gə-aard } & \text { *gaard } & \text { 'natured' }
\end{array}
$$

Second, a prefix boundary always coincides with a syllable boundary. Crucial examples are consonant-final prefixes with vowel-initial stem which violate the Maximal Onset Principle:

$$
\begin{aligned}
& \text { ontaard 'degenerated': (ont) } \left.\left.{ }_{\sigma} \text { (aard }\right)_{\sigma} \text { not: }{ }^{*}(\text { on })_{\sigma} \text { (taard }\right)_{\sigma} \\
& \text { veras 'cremate' (ver) }{ }_{\sigma} \text { (as) } \\
& \text { onaardig 'unkind' } \\
& \text { (on) }{ }_{\sigma}\left(\text { aar) }{ }_{\sigma}(\mathrm{dig})_{\sigma}\right. \\
& *(\text { ve })_{\sigma} \text { (ras) }{ }_{\sigma} \\
& *(\mathrm{o})_{\sigma} \text { (naar) }{ }_{\sigma}(\mathrm{dig})_{\sigma}
\end{aligned}
$$


For German, the occurrence of glottal stops after prefixes before vowel- initial stems also proves the non-cohering nature of prefixes. All these facts follow from the assumption that Dutch and German prefixes are non-cohering. Note, however, that this does not necessarily imply that all prefixes are phonological words by themselves. For prefixes like beand $g e$ - with a schwa as their only vowel, the status of phonological word would be rather problematical, since normally each phonological word contains at least one full vowel. Therefore, it is much more plausible to assign such prefixes the status of 'appendix to a phonological word':

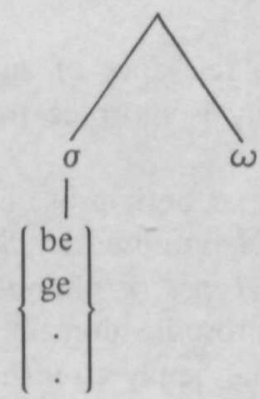

On the other hand, the status of phonological word is clearly justified for those prefixes that induce the same stress pattern as compounds, i.e. main stress on the prefix, as in e.g. ónnationàal 'unnational'.

By assigning be-, ge- etc. the status of appendix, we also correctly predict that they cannot be deleted themselves (by right reduction):

$$
\begin{aligned}
& \text { *bevaren en bॄrijden 'sail and ride' } \\
& \text { *gehijg en g\&puf 'gasping and puffing' }
\end{aligned}
$$

A third class of complex words is the class of words with morphemes which are neither affixes nor lexical morphemes, but roots borrowed from Greek and Latin, such as monoloog 'monologue', bibliografisch bibliographical' and hydrostatica 'hydrostatics'. Word-internal coordination reduction also applies to such words:

$$
\begin{aligned}
& \text { monol } \phi g \notin n \text { en dialogen 'monologues and dialogues' } \\
& \text { bibliografil\$\$ en dactylografische hulp 'bibliographical and } \\
& \text { dactylographical assistance' } \\
& \text { hydro\$1 dif } \$ \text { en aerostatica 'hydrostatics and aerostatics' }
\end{aligned}
$$

These deletion data are accounted for by the assumption that, although these morphemes are not independent lexical items, they are independent

- phonological words. ${ }^{10}$ 


\section{THEORETICAL CONSEQUENCES}

Although rule (21) is conditioned by syntax (the presence of coordination is required) it is not a syntactic transformation, since it applies to phonological constituents, phonological words and projections thereof. Thus, this rule very nicely supports Selkirk's 'Autonomy of Word Structure Condition', which states that "no deletion or movement transformation may involve categories of both W[ord]-structure and S [yntactic]-structure" (cf. note 2). Or, to put it differently, this condition predicts that the reduction rule is a prosodic rule: it cannot apply to morphological constituents since it also involves syntactic structure.

The analysis proposed above also supports the relevance of an independent prosodic structure which is not necessarily isomorphic to morphological/syntactic structure.

Note, however, that the reduction rule refers to both prosodic and syntactic structure. This conflicts with the model proposed by Selkirk (1980a). In that paper, Selkirk distinguishes two types of phonological rule: $\mathrm{L}$ (abeled) $\mathrm{B}$ (racketing)-domain rules and prosodic domain rules. LB-domain rules apply before, prosodic domain rules apply after the conversion of syntactic/morphological structure into prosodic structure:

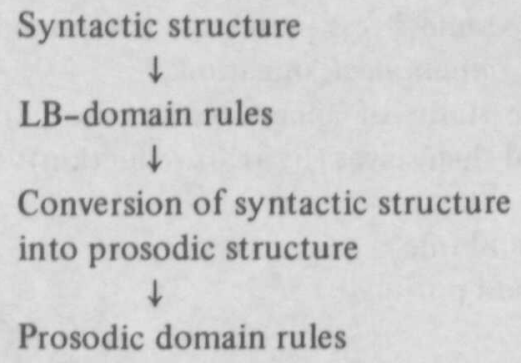

Prosodic domain rules

Clearly, rule (21) does not fit into this model: it is both an LB-domain rule, since it refers to the syntactic notion 'conjunction', and a prosodic rule, since it refers to the notion 'phonological word'.

This problem cannot be solved by reformulating rule (21) as a purely prosodic rule, because in prosodic structure certain crucial syntactic distinctions are obliterated. For instance, according to the rules proposed by Selkirk (1978: 20) and Nespor and Vogel (1982: 228) the strings [de landbouw] en [de tuinbouw] and [de landbouw] [met de tuinbouw $]_{\mathrm{PP}}$ will be assigned the same prosodic structure: 
- (36)
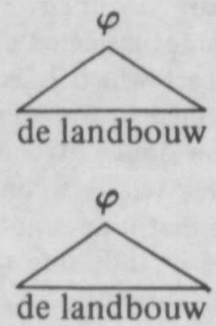
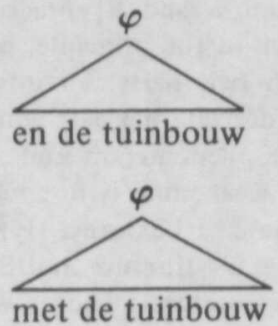

That is, in prosodic structure we cannot differentiate between conjunctions and prepositions. Yet, reduction is impossible in sentences such as (37): ${ }^{11}$

${ }^{*}$ De minister vindt dat [de land $\left.\phi \phi \psi w w\right]_{N P}[\text { met de tuinbouw] }]_{\mathrm{PP}}$ 'The minister thinks that the agriculture with the horticulture moet concurreren

should compete'

Rule (21) is not an isolated case in this respect. Another example from Dutch is the rule that gives us the allomorph - atja of the diminutive suffix from the underlying form / tja/ if the stem ends in a lax vowel plus a sonorant consonant. This rule of schwa-insertion refers to both the notion 'diminutive suffix' (i.e. it is an LB-domain rule) and to the prosodic structure of the stem, since it can only apply if the stem does not end in a metrically weak syllable (cf. Booij 1983).

Another example of a proposed interaction of LB-structure and prosodic structure is Kiparsky's hypothesis (Kiparsky 1979) that the assignment of metrical structure takes place in a cyclic fashion(i.e. in terms of morphological domains). Hayes' rule (Hayes 1982) that English adjectival suffixes are extrametrical also refers to both hierarchies. ${ }^{12}$

Therefore, I conclude that Selkirk's model (35) has to be revised. The direction in which this revision should go is a matter of future research.

\section{NOTES}

1. This paper is based on Booij (1983) as far as the analysis and the Dutch data are concerned. The Dutch data are partly from Bakker (1968), partly my own observations and intuitions. The German data are from Höhle (1982). The English translations of the examples are usually as literal as possible. Examples are always

- from Dutch, unless explicitly stated otherwise.

2. The generalized Lexicalist Hypothesis reads as follows: "syntactic rules are not allowed to refer to, and hence cannot directly modify, the internal morphological structure of words". Selkirk's (1982: 70) formulation of the Word Structure Autonomy Condition is: "No deletion or movement transformation may involve cate- 
gories of both W[ord]-structure and S[yntactic]-structure". Anderson (1982: $591)$ defends a weaker version of the principle, which excludes inflected elements: "morphology is divisible into two parts: an inflectional part which is integrated [...] with the syntax, and a derivational part which is confined to the lexicon and opaque to syntax". Since the phenomenon under discussion does not concern inflected elements, Anderson's weakening is not relevant here. Selkirk's condition is weaker than Lapointe's Generalized Lexicalist Hypothesis in that it does not prevent syntactic rules from analyzing W-structure and S-structure in the same structural description; it only excludes structural changes which alter structures. Again, this difference between Lapointe and Selkirk is not relevant for the present discussion.

3. It only occurs as an independent word in the idiomatic verb-particle combination schei uit 'stop it'.

4. Compare coordinations of non-minimal projections such as het [heel mooie] $\mathrm{AP}$ en [erg dure] AP boek 'the very nice and very expensive book', in which the head boek requires an ending $-e$ for the heads of both $\mathrm{AP}$-conjuncts.

5. I assume that conjunctions may lack a phonological matrix.

6. One might wonder why the prosodic conditions in (21) are conditions on the variable $\mathrm{Y}$, and not on the remnants, for instance: 'the remnants must consist of one or more phonological words'. The reason is that a condition on remnants would be inadequate. Suppose we deleted the suffix $-i g$ in blauwig en rodig "bluish and reddish', which would result in an ungrammatical phrase:

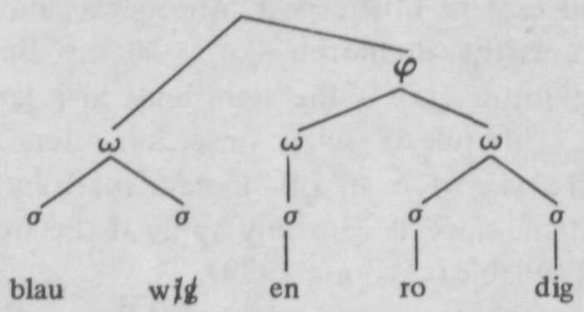

This structure would be ill formed indeed, since the second syllable no longer contains a nucleus. However, this prosodic structure will be resyllabified automatically, as is required after each application of a phonological rule that affects syllable structure. Compare, for instance, the correct schwa-deletion in ploeteren 'to toil': /plut ərən/ $\rightarrow$ [plutrən]. At first, this rule of schwa-deletion will result in the illformed structure (plu) ${ }_{\sigma}(\mathrm{t}){ }_{\sigma}(\mathrm{r} \partial \mathrm{n}){ }_{\sigma}$, but this structure will be resyllabified automatically into (plu) $\sigma$ (tran) $\sigma$. Therefore, a prosodic wellformedness-condition of the sort suggested here would be incorrect, since it would also block the derivation o [plutron].

A second reason is that there are also cases where the remnants or coordination reduction are not phonological words, and yet reduction is possible (cf. section 4 , prefixes).

7. In (23) I have taken the effect of syllable-final devoicing of obstruents into account in describing the syllabification patterns.

9. The distinction between cohering and non-cohering affixes is by no means a distinction for Dutch and German only. Such a distinction is also necessary for, for instance, Estonian and Yidin ${ }^{\mathrm{y}}$ (cf. Booij 1982).

9. Cf. Booij and Rubach (to appear) for evidence that certain English and Polish prefixes are also independent phonological words.

10. English also exhibits this kind of deletion, for instance: mono-and trisyllabic, 
pro- and enclitics, hyper- and hypothyroid, socio- and politicoeconomic (Siegel

- 1974: 47; see also Strauss 1982: 43).

The fact that root-final schwas do not disappear before a following vowelinitial root (as in [tele] [ingenieur] 'telecommunication engineer') also supports this assumption.

11. However, one of my German informants considered a sentence such as Sie ersetzten Ofen-durch Zentralheizung 'They replaced stove heating with central heating' grammatical. It seems then that for this type of speaker the reduction rule has become completely prosodic. Note that constructions such as (Dutch) uit de marco-naar de microwereld 'from the macroworld to the microworld' are correct. But such a construction must clearly be considered as a kind of coordination (with the conjunction uit... naar), because in main clauses the finite verb occurs after this constituent, e.g.: Uit de macro-naar de microwereld is slechts één stap 'From the macroworld to the microworld is only one step'.

12. Other examples are McCarthy's rule of Expletive Infixation (McCarthy 1982) and Harris' assumption that in Spanish syllable structure assignment is cyclic (Harris 1982).

\section{REFERENCES}

Anderson, S.R. (1982), 'Where's morphology? ', Linguistic Inquiry 13, 571-612.

Bakker, D.M. (1968), Samentrekking in Nederlandse syntactische groepen. Leiden: Universitaire Pers.

Booij, G.E. (1982), 'Principles and parameters in prosodic phonology', in: B. Butterworth, B. Comrie, O. Dall (eds.) Explanations for Language Universals. The Hague/Berlin: Mouton.

Booij, G.E. (1983), 'Conjunctiereductie in gelede worden, een terreinverkenning', Spektator 13, 3-19.

Booij, G.E. \& J. Rubach (to appear), 'Morphological and prosodic domains in Lexical Phonology', Phonology Yearbook 1. Cambridge: C.U.P.

Harris, J.W. (1982), 'Spanish syllable structure assignment is cyclic', in J.P. Lantolf \& G.B. Stone (eds.), Current Research in Romance Languages. Bloomington Ind.: IULC.

Hayes, B. (1982), 'Extrametricality and English stress', Linguistic Inquiry 13, 227. 76.

Höhle, T.N. (1982), 'Uber Komposition und Derivation: zur Konstituentenstruktur von Wortbildungsprodukten im Deutschen', Zeitschrift für Sprachwissenschaft 1. 76-112.

Jackendoff, R.S. (1977), $\bar{X}$ Syntax. A Study of Phrase Structure. Cambridge Mass.: MIT Press.

Kiparsky, P. (1979), 'Metrical structure assignment is cyclic', Linguistic Inquiry 10, 421-42.

McCarthy, J.J. (1982), 'Prosodic structure and Expletive Infixation', Language $58,574-90$.

Lapointe, S. (1979), 'A lexical analysis of the English auxiliary verb system', GLOT 2, 215-54.

- Nespor, M. and I. Vogel (1982), 'Prosodic domains of external sandhi rules', in H. van der Hulst and N. Smith (eds.) The Structure of Phonological Representations. Dordrecht: Foris, 225-56.

Neijt, A. (1979), Gapping. A Contribution to Sentence Grammar. Dordrecht: Foris. 
Selkirk, E.O. (1978), 'On prosodic structure and its relation to syntactic structure', IULC.

Selkirk, E.O. (1980a), 'Prosodic domains in phonology: Sanskrit revisited', in M. Aronoff and M.-L. Kean (eds.), Juncture. Saratoga Calif.: Anma Libri, 10729.

Selkirk, E.O. (1980b), 'The role of prosodic categories in English word stress', Linguistic Inquiry 11, 563-606.

Selkirk, E.O. (1982), The Syntax of Words. Cambridge Mass.: MIT Press.

Siegel, D. (1974), Topics in English Morphology. MIT-diss.

Strauss, S.L. (1982), Lexicalist Phonology of English and German. Dordrecht: Foris.

Toman, J. (1981), 'Koordination und Wortstruktur', Arbeitsbericht no. 14, DFGProjekt Nominalkomposita, Universität Regensburg.

Zee, N. van der (1982), 'Samentrekking als transformationeel zorgenkindje', GLOT 5, 77-106. 